\title{
FRESHWATER CRAYFISH IN SOUTH TYROL (ITALY): DISTRIBUTION AND PROTECTION MEASURES OF ENDANGERED AUSTROPOTAMOBIUS PALLIPES.
}

\author{
L. FÜREDER (1), B. OBERKOFLER (1), R. HANEL (1), Y. MACHINO (2)
}

\begin{abstract}
(1) University of Innsbruck, Institute of Zoology and Limnology, Technikerstr. 25, A-6020 INNSBRUCK, Austria. E-mail : leopold.fuereder@uibk.ac.at

(2) 13 rue de Montorge, F-38000 GRENOBLE, France.
\end{abstract}

\begin{abstract}
Freshwater crayfish are among the most endangered animals in Europe. Information on freshwater crayfish in the Italian province of South Tyrol was insufficient until the recent studies on their historical and present distribution, which showed the alarming facts that only 15 standing and running waters remained as freshwater crayfish habitats, carrying the native Austropotamobius pallipes and the allochthonous Astacus astacus, Orconectes limosus, and Pacifastacus leniusculus. Still ongoing alterations or degradation of water bodies have contributed to the high degree of population decline and loss. While the exotic crayfish $O$. limosus and $P$. leniusculus could develop higher densities, most of the autochthonous $A$. pallipes populations were weak and consisted only of a few individuals. Three populations of $A$. pallipes, however, remained in a good condition, representing potential sources for recovery programs. Protection measures currently carried out in South Tyrol involve breeding, restocking and reintroduction of autochthonous A. pallipes individuals in ecological intact water bodies.
\end{abstract}

Key-words: crayfish, Austropotamobius pallipes, geographical distribution, conservation, Tyrol, Bolzano.

\section{LES ÉCREVISSES DANS LE TYROL DU SUD (ITALIE) : DISTRIBUTION ET MESURES DE PROTECTION D'UNE ESPÈCE MENACÉE D'EXTINCTION, AUSTROPOTAMOBIUS PALLIPES.}

\section{RÉSUMÉ}

Les écrevisses autochtones sont considérées comme animaux les plus en danger de nos eaux européennes. Bien que l'information soit nécessaire, celle sur les écrevisses du Tyrol du sud (Italie) était pratiquement inexistante. Récemment, plusieurs études sur 
leur répartition géographique historique et actuelle ont sonné l'alarme en montrant que seuls 15 cours d'eau hébergeaient les écrevisses dans cette province italienne, dont 12 avec Austropotamobius pallies, un avec Astacus astacus, un avec Pacifastacus leniusculus et un avec Orconectes limosus. Les altérations et dégradations de cours d'eau, qui continuent encore de nos jours, ont poussé plusieurs populations d'écrevisses autochtones à régresser voire même à disparaître. Tandis que les espèces exotiques $P$. leniusculus et $O$. limosus ont pu se développer assez fortement, la plupart des populations d'A. pallipes restent faibles et ne sont constituées que d'individus peu nombreux. Trois populations d'A. pallipes, néanmoins, demeurent en bonne condition, représentant donc les sources potentielles pour les programmes de réintroduction. Les mesures de protection effectuées actuellement dans le Tyrol du sud concernent surtout l'élevage et la réintroduction d'A. pallipes autochtone dans les eaux écologiquement intactes.

Mots-clés : écrevisse, Austropotamobius pallipes, répartition géographique, conservation, Tyrol, Bolzano.

\section{INTRODUCTION}

Freshwater crayfish are among the most endangered species of European lakes and rivers. The crayfish plague, Aphanomyces astaci Schikora, a fungus formerly endemic to North America but introduced to Europe towards the end of the $19^{\text {th }}$ century, and predominantly the multiple degradation of rivers and lakes by human activities were responsible for the decline of autochthonous crayfish populations in many European regions.

Accordingly, in Austria both the noble crayfish Astacus astacus (Linnaeus, 1758), well recorded in North/East Tyrolean waters since the Middle Ages (FÜREDER and MACHINO, 1999a), and the autochthonous stone crayfish Austropotamobius torrentium (Schrank, 1803) are considered as highly endangered species (PRETZMANN, 1994). In the Italian province of South Tyrol (= Bolzano), the autochthonous white-clawed crayfish Austropotamobius pallipes (Lereboullet, 1858) is also reported to be highly threatened (BALDASSI, 1993; ADAMI and GASSER, 1994; HELLRIGL and THALER, 1996).

From historical data, however, one can conclude that freshwater crayfish were formerly distributed wider and crayfish locations were found in many lakes, brooks, and rivers throughout Noth/East Tyrol and South Tyrol till the beginning of the $20^{\text {th }}$ century (FÜREDER and MACHINO, 1999a).

Between countries as well as regions there were vital trades providing individual water bodies with economic value. But during the last two centuries, habitat alteration and degradation, like river regulation, damming, and amelioration of swamps and wetlands, were responsible for the decline of natural crayfish populations because these transformations by human caused a major loss of natural habitats. Whereas increasing higher amounts of particulate and dissolved organic matter through water pollution were reported to have a negative effect on some species, toxic substances are considered to harm all species. Accordingly, water pollution, river regulation, and the introduction of exotic and allochthonous crayfish species have changed the natural habitat and the situation of crayfish species, leading to a progressive decrease of distribution areas and the decline of natural populations in Austria and neighbouring countries (FÜREDER and MACHINO, 1999a; FÜREDER and OBERKOFLER, 2000; PETUTSCHNIG, 2000; STUCKI, 2000).

As in other regions of Austria and Italy as well as other parts of Europe, little information on freshwater crayfish was available from North/East Tyrol and South Tyrol 
(FÜREDER and MACHINO, 1998, 1999a). Only scattered knowledge from locally restricted investigation was available (e.g. FÜREDER and MACHINO, 1995, 1996, 1999a, b; MACHINO and FÜREDER, 1998). In order to estimate the present situation of freshwater crayfish and to evaluate the level of their threat, distribution studies in whole Tyrol were started in 1998.

In this paper we provide comprehensive information on the present status of freshwater crayfish in the Austrian (North/East Tyrol) and Italian (South Tyrol) provinces of Tyrol, concentrate on reasons for the decline of populations in South Tyrol, and discuss examples of protection measures in ongoing projects for the threatened Austropotamobius pallipes as one of the only two autochthonous crayfish species in Italy (i.e. A. pallipes and A. torrentium, see MACHINO, 1996; DELMASTRO, 2000).

\section{METHODS}

Historical and recent information on crayfish locations was collected through comprehensive literature and data research (detailed preliminary results were provided in FÜREDER and MACHINO, 1999a) and used in both provinces as a base for proceeding investigations. A questionnaire was sent to responsible governmental departments, environmental agencies, fishery authorities, owners, and tenants of lakes and fishing rights, as well as various other people.

In the identified regions potentially carrying crayfish, running and standing waters known and/or suspected to hold freshwater crayfish were investigated, mainly during the warm months. Field work was carried out from 1998 to 2001. As a first orientation, the water bodies in consideration were assessed for describing their ecological status, habitat condition, and existing impacts; adapting the assessment form from BOHL (1989).

Collecting methods used were various, depending on type, size and depth of the water body or sampling reach. They were performed generally by observations and hand catches during the night but where waters were too deep, crayfish traps were fished for one night and emptied the following morning.

All results were included in a database with the necessary details of the record, GIS-based distribution maps were produced for each region.

\section{RESULTS AND DISCUSSION}

\section{Freshwater crayfish species in the provinces of Tyrol}

The present freshwater crayfish inventories resulted in records of five species being found in the Austrian province of North/East Tyrol, while in the Italian province of South Tyrol four species live (Table I). In North and East Tyrol the noble crayfish Astacus astacus and the stone crayfish Austropotamobius torrentium are considered autochthonous species, and in South Tyrol the white-clawed crayfish Austropotamobius pallipes only. Three allochthonous species occur in North/East Tyrol, i.e. the narrow-clawed crayfish Astacus leptodactylus (Eschscholz, 1823), the white-clawed crayfish A. pallipes and the signal crayfish Pacifastacus leniusculus (Dana, 1852); in South Tyrol allochthonous species are the noble crayfish $A$. astacus, the signal crayfish $P$. leniusculus, and the spiny-cheek crayfish Orconectes limosus (Rafinesque, 1817). 


\section{Table I}

Freshwater crayfish water bodies in North/East and South Tyrol: occurring species and number of water bodies (lake and its outflow are considered as one water body).

\section{Tableau I}

Les cours d'eau à écrevisses dans le Tyrol du nord-est et dans celui du sud : espèces rencontrées et nombre de cours d'eau (le lac et son émissaire sont considérés comme un seul cours d'eau).

\begin{tabular}{lcc}
\hline Species & $\begin{array}{c}\text { Number of } \\
\text { water bodies } \\
\text { North/East Tyrol } \\
\text { (Austria) }\end{array}$ & $\begin{array}{c}\text { Number of } \\
\text { water bodies } \\
\text { South Tyrol } \\
\text { (Italy) }\end{array}$ \\
\hline A. astacus (Linnaeus, 1758) & 35 & 1 \\
A. leptodactylus (Eschscholz, 1823) & 3 & - \\
A. torrentium (Schrank, 1803) & 2 & - \\
A. pallipes (Lereboullet, 1858) & 3 & 12 \\
P. leniusculus (Dana, 1852) & 1 & 1 \\
O. limosus (Rafinesque, 1817) & - & 1 \\
Total number & $\mathbf{4 4}$ & $\mathbf{1 5}$ \\
\hline
\end{tabular}

The present investigation resulted in a total of 15 crayfish locations in the water bodies of South Tyrol (Table I, Figure 1). Most crayfish waters carried the autochthonous crayfish Austropotamobius pallipes, and only one location had Astacus astacus, which turned out to be the first record for noble crayfish for Italian Tyrol (OBERKOFLER et al., 2002). Each of the two North American species occurred in one water body (MACHINO, 1997; FÜREDER and MACHINO, 1999b; OBERKOFLER, 2000): O. limosus in Vahrner See, an artificial lake north of the town of Brixen (= Bressanone), and $P$. leniusculus in the Auenbach.

In North/East Tyrol in Austria, where a total of 44 running and standing waters with crayfish populations was reported (FÜREDER and HANEL, 2000), four European species and one American species were found: $A$. astacus in most waters (27 lakes or ponds, eight streams), $A$. torrentium in two (one river and one lake), $A$. pallipes in three (two lakes and one pond), $A$. leptodactylus in three ponds, and $P$. leniusculus in one pond.

Owing the mountainous topography of both provinces, freshwater crayfish generally occurred at lower elevations in lakes and rivers of the bigger valleys, where temperature regime and channel stability enable the successful survival of crayfish populations. In South Tyrol, only one location with $A$. pallipes is situated above $1000 \mathrm{~m}$ a.s.l. (the Krebusbach), five were found between 600 and $1000 \mathrm{~m}$ a.s.l., and nine between 200 and $600 \mathrm{~m}$ a.s.l.

There tends to be a strong decrease in number of crayfish waters in all parts of Tyrol (of Austria and Italy), given the information that about 50 locations were recorded in literature (FÜREDER and MACHINO, 1999; OBERKOFLER, 2000). The comparison with former distribution studies in South Tyrol shows that even within the last two to three decades, the crayfish situation became worse (Table II). The « apparent » higher number of recent crayfish sites is simply a result of a more detailed and extensive study by OBERKOFLER (2000). In the different parts of the province, the populations either declined or became extinct. At one location (Auenbach) the introduction of exotic species wiped out the native $A$. pallipes. 

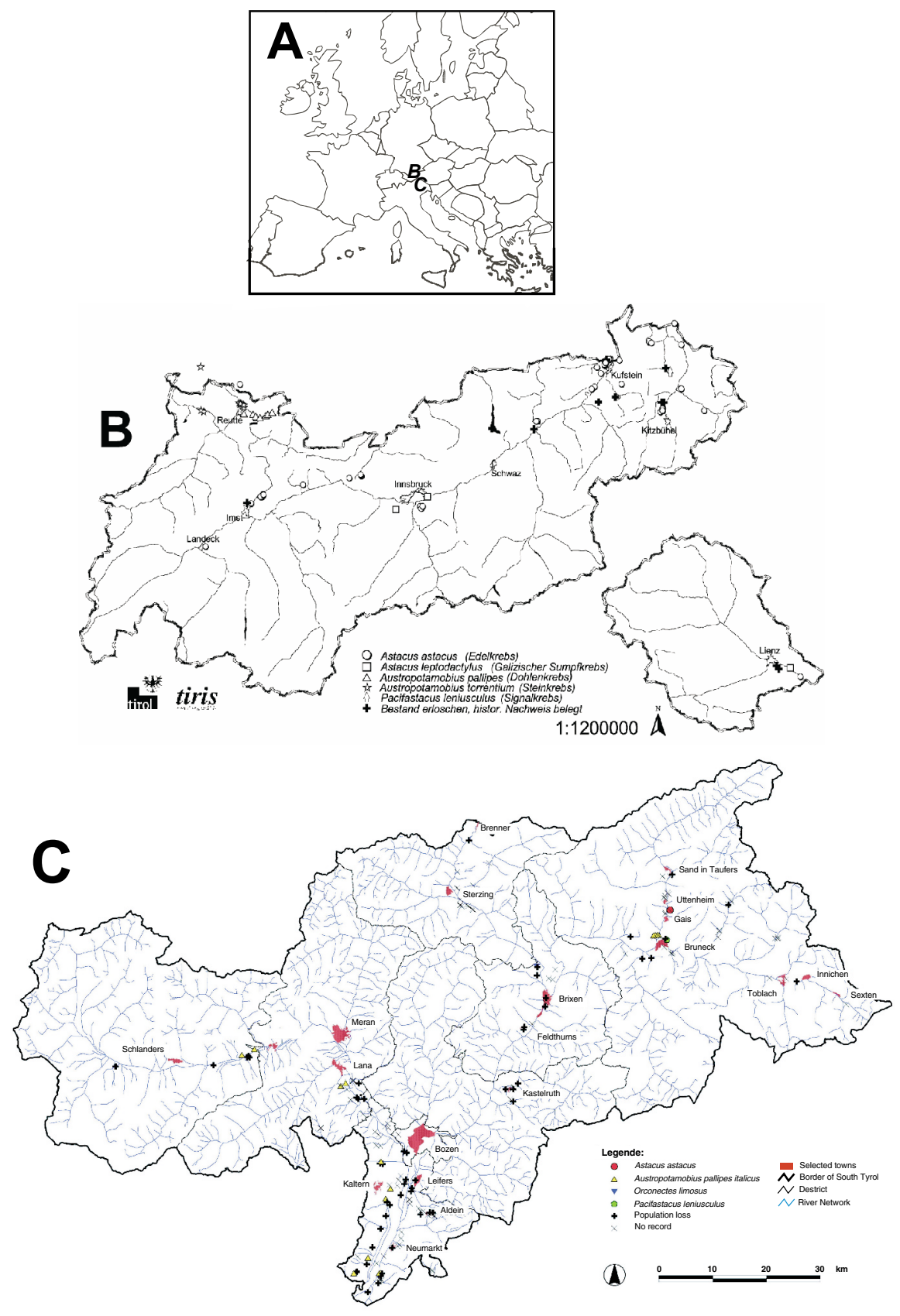

Figure 1

Distribution maps of freshwater crayfish inventories: A) location of the provinces of Tyrol, i.e. B) North/East Tyrol in Austria, and C) South Tyrol in Italy (map B provided by Tiroler Raumordnungs-Informationssystem tiris, Amt der Tiroler Landesregierung, -Helmut Guglberger, June 1999; map C provided by Autonome Provinz Bozen, produced by C.M.E. Hansen, June 2000).

\section{Figure 1}

Cartes de répartition géographique des écrevisses : A) localisation des provinces de Tyrol, i.e. B) Tyrol du Nord et de l'Est en Autriche, et C) Tyrol du Sud en Italie (carte B fournie par le Tiroler Raumordnungs-Informationssystem tiris, Amt der Tiroler Landesregierung, -Helmut Guglberger, juin 1999 ; carte C fournie par l'Autonome Provinz Bozen, faite par C.M.E. Hansen, juin 2000). 
Table II

Comparison of former distribution studies in the Italian province of South Tyrol.

\section{Tableau II}

Comparaison des études anciennes sur la répartition dans le Tyrol du Sud en Italie.

\begin{tabular}{|c|c|c|c|}
\hline & $\begin{array}{l}\text { SCHENK et al. } \\
\text { (1978) }\end{array}$ & $\begin{array}{c}\text { BALDASSI } \\
\text { (1993) }\end{array}$ & $\begin{array}{c}\text { OBERKOFLER } \\
(\mathbf{2 0 0 0 )}\end{array}$ \\
\hline \multicolumn{4}{|l|}{ Vinschgau } \\
\hline Staudenbach & - & & + \\
\hline Krebsbach & ๑0 & & ( \\
\hline Gießbach & $\bullet$ & & $\bullet$ \\
\hline \multicolumn{4}{|l|}{ Burggrafenamt } \\
\hline $\begin{array}{l}\text { Krebsbach Lana } \\
\text { Hyppolithbach }\end{array}$ & $\bullet \bullet \bullet$ & $\bullet$ & $\stackrel{0}{\circ}$ \\
\hline \multicolumn{4}{|l|}{ Überetsch-Unterland } \\
\hline Kalterer See & $\bullet$ & - & + \\
\hline Stream in Aldein & $(\bullet)$ & - & + \\
\hline Thalerbach & $\bullet$ & + & \\
\hline Stream in Putzertal & ( & - & \\
\hline Fennersee & 0 & + & \\
\hline Krebusbach & $\bullet$ & $\bullet \bullet$ & $\bullet$ \\
\hline Wiesenbach/Kaltern & & $\bullet$ & + \\
\hline Angelbach & & $\bullet \bullet \bullet$ & $\bullet \bullet$ \\
\hline Laager Gräben & & $\bullet$ & $\bullet$ \\
\hline Pfattner Gräben & & - & + \\
\hline Krebsbach Kaltern & & & $\bullet$ \\
\hline Wasserschacht/Englar & & & $\bullet$ \\
\hline Entiklarbach & & & $\bullet \bullet$ \\
\hline \multicolumn{4}{|l|}{ Eisacktal } \\
\hline Vahrner See & + & - & O. limosus \\
\hline \multicolumn{4}{|l|}{ Pustertal } \\
\hline Auenbach & ๑०० & & P. leniusculus \\
\hline Moosbachl & & & $\bullet$ \\
\hline Wiesenbach & & & $\bullet \bullet \bullet$ \\
\hline
\end{tabular}

\section{Land-use activities and freshwater crayfish}

Historical records provided evidence that freshwater crayfish had a wider distribution in several areas of North/East Tyrol and South Tyrol. These historical crayfish records were located especially in the broader main valleys, where variable water bodies and courses developed under natural conditions (from wetlands, ponds, and slow to fast flowing rivers), as well as on higher plateaus. However, in a mountainous area like Tyrol, these flat and exposed areas were regarded ideal for settlement and cultivation. Channel alteration and drainage measures of wetlands were the consequence of increasing land-use activities. Although in most cases the actual cause for crayfish loss and decline is difficult to ascertain, land use and cultivation practices seem to be one of the major threats to native freshwater crayfish. In our investigation we characterized a selection of 120 water courses, recorded either as historical/present or potential (when located in the vicinity of a record) crayfish water. Almost $40 \%$ the stream sectors investigated had between no and little riparian vegetation (Figure 2). 


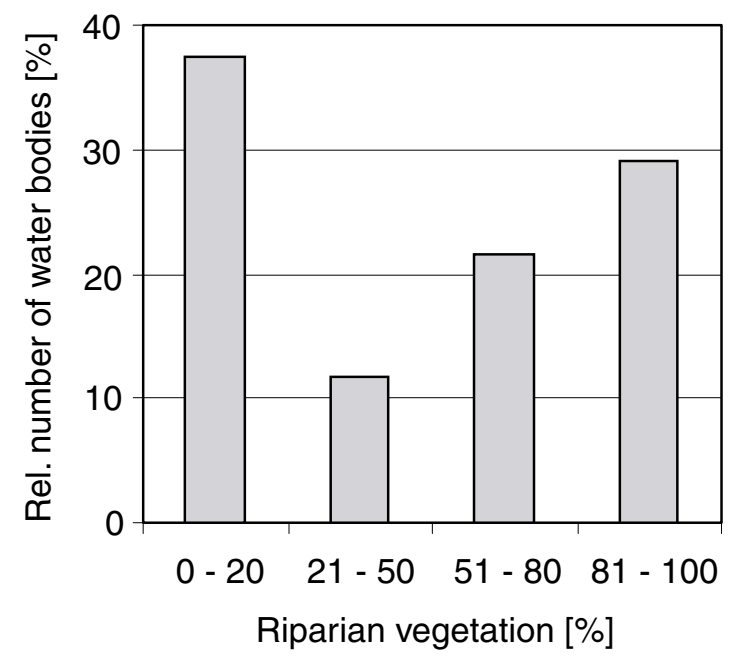

Figure 2

Results from habitat assessments in South Tyrol carried out at 120 stream sectors selected according to historical and present crayfish records.

\section{Figure 2}

Résultats de l'évaluation des habitats, effectuée dans le Tyrol du Sud, sur les 120 secteurs de ruisseaux choisis d'après les données historiques et actuelles sur les écrevisses.

To some extent, riparian vegetation can be portrayed as an indicator of degree of naturalness and habitat availability. On the other hand, the lack of riparian vegetation is reflecting malfunction and ineffective buffer strips. Riparian corridors are considered an essential landscape element for protecting freshwater ecosystems from agricultural and industrial effluents (Figure 3).

\section{Foreign crayfish species in North and South Tyrol}

After the decrease of native crayfish populations in European waters, doubtful attempts were performed in several regions of Austria and Italy to introduce exotic species, like the signal crayfish $P$. leniusculus and the spiny-cheek crayfish $O$. limosus. UNESTAM (1975) already warned that not only uncontrolled transfer of crayfish may introduce new crayfish parasites which can alter and seriously harm other animals, including man, but also crayfish themselves may be vectors of fish pathogens such as viruses. Harmless commensals or parasites on introduced crayfish may become aggressive to autochthonous crayfish or to other animals in the new environment. The new crayfish may also become a pest itself.

An example of the introduction of organisms with non-native crayfish is well known in Europe, having resulted in population losses of autochthonous crayfish in many regions (HOLDICH, 1988; LOWERY and HOLDICH, 1988). The signal crayfish Pacifastacus leniusculus has been introduced into several European countries since the 1960 s and is now widely distributed in Europe. It is currently displacing the native crayfish Astacus astacus in Sweden and Austropotamobius pallipes in the U.K. (SÖDERBÄCK, 1995; HOLDICH and DOMANIEWSKI, 1995). A powerful mechanism governing these species replacements is the transmission of the crayfish plague. Being itself resistant against the crayfish plague, $P$. lenuisculus acts as a vector of the disease which causes complete mortality in all European crayfish species (ALDERMAN and POLGLASE, 1988; ALDERMAN et al., 1990). Indeed several countries have been affected and some regions are still suffering from the crayfish plague. 


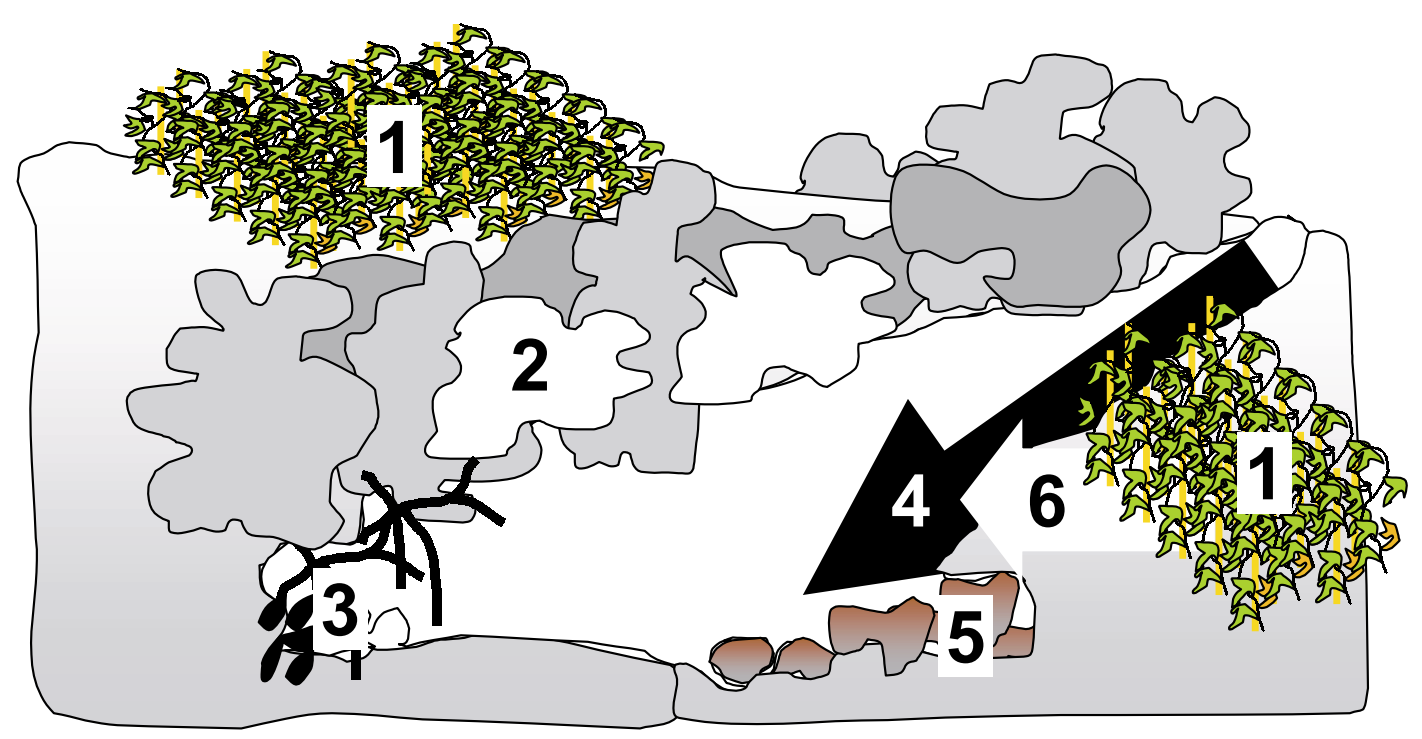

Figure 3

Potential benefits from riparian corridors: natural buffers for crayfish habitats. Land use and cultivation (1) in two scenarios - A) with riparian vegetation: (2) buffer strip withholding and filtering agricultural and industrial effluents, (3) increasing habitat complexity and food variability; B) without riparian vegetation: (4) increased bank erosion and turbidity, (5) increased mobilisation of sediment and substrate and (6) unhindered influx of effluents (including fertilizers, herbicides and pesticides).

\section{Figure 3}

Avantages potentiels des couloirs de végétation riveraine: zone de tampon naturel pour les habitats d'écrevisses. L'utilisation de terre et la culture (1) en deux scénarios - A) avec végétation riveraine : (2) la zone de tampon qui retient et filtre les effluents agricoles et industriels, et (3) qui augmente la complexité des habitats et la variabilité alimentaire; B) sans végétation riveraine : (4) l'augmentation d'érosion des rives et de turbidité, (5) l'augmentation de la mobilisation de sédiment et substrat, et (6) le libre influx des effluents (y compris les engrais, herbicides et pesticides).

Moreover, mixed populations of apparently plague-free $P$. leniusculus with $A$. astacus or $A$. pallipes have ever been documented (HOLDICH and DOMANIEWSKI, 1995; SÖDERBÄCK, 1995). In these populations, $P$. leniusculus gradually replaced the native crayfish, suggesting that behavioural or ecological mechanisms may be sufficient to cause species replacements.

In Switzerland STUCKI (1997) recently reported $P$. leniusculus from several locations. VORBURGER and RIBI (1999a) expected $P$. leniusculus to spread successfully and threaten the remaining populations of the native crayfish species $A$. astacus, $A$. pallipes and $A$. torrentium. Of particular concern is its possible effect on $A$. torrentium, a rare species in Switzerland about which little is known. There it is restricted to the north eastern and central parts of the country (BÜTTIKER, 1988), inhabiting small brooks, but also forming lake populations. No sympatric populations of $P$. leniusculus and $A$. torrentium are known so far, but VORBURGER and RIBI (1999b) expected these two species to come into contact within a few years. 
Also in Austria $P$. leniusculus was introduced into many lentic and lotic waters (PÖCKL, 1999).

All the American species in North Tyrol ( $P$. leniusculus) and South Tyrol (O. limosus and $P$. leniusculus) are a great threat to the remaining autochthonous populations. In South Tyrol, at one location with signal crayfish (i.e. the Auenbach), the autochthonous $A$. pallipes has already been replaced by this foreign species and is totally extinct now. Also in Vahrner See the presence of spiny-cheek crayfish suppresses any hope of reintroducing the native crayfish species (Table II). Now the neighbouring native crayfish are in danger (e.g. FÜREDER and MACHINO, 1999b). Since both exotic populations are restricted to single water bodies, effort should be put into trapping and electro-fishing to obtain a sustained decline and final deletion of the populations. The alarmingly low number of native crayfish populations in South Tyrol strengthens this argument.

\section{Future prospects for Tyrolean freshwater crayfish}

In North/East Tyrol and South Tyrol, the results of our current crayfish inventories provided water authorities, environmental protection agencies and the public with the alarming fact that freshwater crayfish dramatically declined, compared to their historical distribution (see Figure 1; FÜREDER and MACHINO, 1999a).

Giving the evidence of current threats in South Tyrol, such as the presence of allochthonous species potentially carrying the crayfish plague, ongoing degradation of water bodies, and intensified land-use practices in the catchments, the low number of crayfish waters guarantees the native crayfish neither to recover nor even to survive. Without human action, these last remaining populations would decline further or disappear.

Nevertheless, optimistic evidence is provided by the enhancement of environmental conditions in some areas (waste water treatment, reduction of pesticides and herbicides) and the improvement of structural conditions of water courses, therefore providing potential suitable habitats for the introduction or re-stocking of native crayfish species. Public awareness also increased, a prerequisite of environmental protection strategies.

The ongoing decline and acute threats to native crayfish populations require specific measures for improvement of the situation. Measures for sustainable protection of crayfish habitats are considered as a priority objective in stream ecology and nature conservation. In Tyrol (of Austria and Italy), we started several projects in collaboration with water authorities and environmental protection agencies in order to provide specific knowledge on the decline of the autochthonous species in individual water bodies, like $A$. torrentium in North Tyrol, $A$. astacus in East Tyrol and $A$. pallipes in South Tyrol, coupled with riverrestoration measures and well-balanced examples of re-introduction in intact or restored water bodies. The performance of these projects follow a general common strategy with adaptations to regional characteristics:

- a substantial prerequisite for healthy crayfish populations is an intact freshwater habitat. Suggestions and measures include improving structural conditions (stream restoration) and reducing environmental stress (riparian corridors buffering agricultural and industrial effluents).

- detailed investigations on individual crayfish populations, breeding, re-introductions and re-stockings will enhance the situation on a regional perspective.

- public relations and information are important in all phases of the projects. 
These protection measures in the province of South Tyrol were started in 1999. But for a sustainable protection of species and improvement of the precarious situation, continuous detailed observation and long-term monitoring, accompanied by ecological experiments and investigations, are essential prerequisites. The embedding into national and international programs and projects will strengthen further local activities to support the survival of native freshwater crayfish, comprising a unique culture-historical and ecological value.

As a general observation on the status of freshwater crayfish in North/East Tyrol and South Tyrol, one must state that compared to other areas of Central Europe only a few crayfish locations now remain. Present distribution studies and inventories showed that especially the structural changes of rivers and lakes as well as the careless and intensive land-use activities led to a dramatic decline of crayfish waters. The value of the remaining populations reaches a high significance, not only because they are the real last ones of their kind in Tyrolean waters but also because they can be regarded as indicator organisms for the reference conditions of stream and lake habitats. A species group with which man still combines history and culture (fasting meals, royal hunting and fishing activities) as well as memories of childhood (crayfish chasing was well known in former times among children), proposed management plans should support and establish a new relationship between human and crayfish.

\section{ACKNOWLEDGEMENTS}

We are grateful to several institutions, public and private persons that provided substantial help and input into the crayfish inventories, hence enabling the current knowledge on freshwater crayfish distribution in the provinces of North/East and South Tyrol. We also thank the authorities of the Autonome Provinz Bozen and the Tiroler Landesregierung for funding past and ongoing projects and their help in providing maps and establishing links. For their detailed information on past and present crayfish locations we express our thanks to fishery authorities, owners and tenants of water bodies and fishing rights, as well as public and private people.

\section{REFERENCES}

ADAMI V., GASSER M., 1994. Rote Liste der gefährdeten Zehnfußkrebse (Decapoda) Südtirols. In: ABTEILUNG FÜR LANDSCHAFT- UND NATURSCHUTZ DER AUTONOMEN PROVINZ BOZEN-SÜDTIROL (ed.), Rote Listen gefährdeter Tiere Südtirols, 23-33 + 348-349, Amt für Landschaftsplanung, Autonome Provinz BozenSüdtirol, Bozen/Bolzano.

ALDERMAN D.J., POLGLASE J.L., 1988. Pathogens, parasites and commensals. In : HOLDICH D.M. and LOWERY R.S. (Eds.), Freshwater crayfish: biology, management and exploitation, 167-212 + 426-479, Croom Helm, London.

ALDERMAN D.J., HOLDICH D., REEVE I., 1990. Signal crayfish as vectors in crayfish plague in Britain. Aquaculture, 86, 3-6.

BALDASSI L., 1993. II gambero (Austropotamobius pallipes italicus) nelle acque correnti dell'Alto Adige : distribuzione spaziale in relazione alle caratteristiche ambientali e alla qualità delle acque. Tesi di Laurea, Dipartimento di Biologia Evoluzionistica Sperimentale, Facoltà di Scienze Matematiche, Fisiche e Naturali, Università degli Studi di Biologna, Bologna, 6 pl. + 1 map +74 p.

BOHL E., 1989. Ökologische Untersuchungen an ausgewählten Gewässern zur Entwicklung von Zielvorstellungen des Gewässerschutzes: Untersuchungen an Flußkrebsbeständen. Ber. Bayer. Landesanst. Wasserforsch., (13), x + 237 p. +2 pl. 
BÜTTIKER B., 1988. Concerning crayfish in Switzerland. In : GOELDLIN DE TIEFENAU P. (ed.), Freshwater Crayfish, vol. 7, 2-5, Musée Zoologique Cantonal, Lausanne.

DELMASTRO G.B., 2000. Un gambero a stelle e strisce alla conquista dei nostri ambienti acquatici. Piemonte Parchi, 15 (6), 2-5.

FÜREDER L., HANEL R., 2000. Flusskrebse in Gewässern Nord- und Osttirols: Verbreitung, ökologische Bedeutung und Schutzmaßnahmen. Ber. naturwiss.-med. Verein Innsbruck, 87, 221-241.

FÜREDER L., MACHINO Y., 1995. Record of the white-clawed crayfish Austropotamobius pallipes (Lereboullet, 1858) from Plansee (Tyrol, Austria). Ber. naturwiss.-med. Verein Innsbruck, 82, 241-246.

FÜREDER L., MACHINO Y., 1996. Das letzte natürliche Vorkommen des Steinkrebses Austropotamobius torrentium (Schrank, 1803) in Tirol. Ber. naturwiss.-med. Verein Innsbruck, 83, 211-219.

FÜREDER L., MACHINO Y., 1998. Historische und rezente Flußkrebsvorkommen in Tirol, Südtirol und Vorarlberg. Stapfia, 58 (137), 77-88 + Berichtigungen.

FÜREDER L., MACHINO Y., 1999a. Past and present situation of freshwater crayfish in Tyrol (Austria and northern Italy). In : KELLER M, KELLER M.M., OIDTMANN B., HOFFMANN R. and VOGT G. (Eds.), Freshwater Crayfish, vol. 12, 751-764, Weltbild Verlag, Augsburg.

FÜREDER L., MACHINO Y., 1999b. Les écrevisses exotiques dans le Tyrol du Sud (Italie). L'Astaciculteur de France, 61, 2-6.

FÜREDER L., OBERKOFLER B.M., 2000. Flusskrebse in den Gewässern Südtirols : Verbreitung, ökologische Bedeutung, Gefährdung und Schutzmaßnahmen. Studie im Auftrag der Autonomen Provinz bozen, 127 p. (unpublished).

HELLRIGL, K., THALER B., 1996. Klasse Krebstiere - Crustacea. In : HELLRIGL K. (ed.), Veröffentlichungen des Naturmuseums Südtirol, Bozen, Band 1: Die Tierwelt Südtirols, 250-261, Naturmuseum Südtirol, Bozen/Bolzano.

HOLDICH D.M., 1988. The dangers of introducing alien animals with particular reference to crayfish. In : GOELDLIN DE TIEFENAU P. (ed.), Freshwater Crayfish, vol. 7, XV-XXX, Musée Zoologique Cantonal, Lausanne.

HOLDICH D.M., DOMANIEWSKI J.C.J., 1995. Studies on a mixed population of the crayfish Austropotamobius pallipes and Pacifastacus leniusculus in England. In : GEDDES M.C., FIELDER D.R. and RICHARDSON A.M.M. (Eds.), Freshwater Crayfish, vol. 10, 37-45, Louisiana State University, Baton Rouge (Louisiana).

LOWERY R.S., HOLDICH D.M., 1988. Pacifastacus leniusculus in North America and Europe with details of the distribution of introduced and native crayfish species in Europe. In : HOLDICH D.M. and LOWERY R.S. (Eds.), Freshwater crayfish: biology, management and exploitation, 282-308 + 426-479, Croom Helm London.

MACHINO Y., 1996. L'écrevisse de torrent Austropotamobius torrentium (Schrank, 1803) est bord de l'extinction en Italie. L'Astaciculteur de France, 49, 9-12.

MACHINO Y., 1997. Présence de l'écrevisse de Californie (Pacifastacus leniusculus) en Italie. L'Astaciculteur de France, 52, 2-5.

MACHINO Y., FÜREDER L., 1998. Der Steinkrebs Austropotamobius torrentium (Schrank, 1803) im Haldensee (Tirol) und weitere Nachweise von Flusskrebsen in hochgelegenen Gewässern. Ber. naturwiss.-med. Verein Innsbruck, 85, 223-229.

OBERKOFLER B.M., 2000. Vorkommen und Verbreitung von Flusskrebsen (Decapoda, Astacidae) in den Gewässern Südtirols. Diplomarbeit, Institut für Zoologie und Limnologie, Universität Innsbruck, Innsbruck, $118 \mathrm{p}$.

OBERKOFLER B., MACHINO Y., FÜREDER L., 2002. Occurrence of the noble crayfish (Astacus astacus) in Italy. Ber. naturwiss.-med. Verein Innsbruck, 89, in press.

PETUTSCHNIG J., 2000. Flusskrebsstudien in Kärnten. In: Kurzfassung der Tagungsbeiträge, Internationale Fachtagung in Klagenfurt « Flusskrebse : Aktuelle Verbreitung, Gefährdung \& Schutz ", Institut für Ökologie und Umweltplanung, Klagenfurt, 34-45 (unpublished).

PÖCKL M., 1999. Distribution of crayfish species in Austria with special reference to introduced species. In : KELLER M, KELLER M.M., OIDTMANN B., HOFFMANN R. 
and VOGT G. (Eds.), Freshwater Crayfish, vol. 12, 733-750, Weltbild Verlag, Augsburg.

PRETZMANN G., 1994. Rote Liste der Zehnfüßigen Krebse (Decapoda) und Schwebegarnelen (Mysidacea) Österreichs. In: GEPP J. (ed.), Grüne Reihe, Band 2: Rote Listen gefährdeter Tiere Österreichs, 31-34 + 279-282 + 336, Bundesministerium für Umwelt, Jugend und Familie, Wien.

SCHENCK I., LADURNER F., WIESER H., 1978. Krebsevorkommen in Südtirol. Tätigkeitsber. Biol. Labors Leifers, 1, 149-165 + 1 photo +1 pl.

SÖDERBÄCK B., 1995. Replacement of the native crayfish Astacus astacus by the introduced species Pacifastacus leniusculus in a Swedish lake: possible causes and mechanisms. Freshwater Biology, 33, 291-304.

STUCKI T.P., 1997. Three American crayfish species in Switzerland. In : MOMOT W.T. (ed.), Freshwater Crayfish, vol. 11, 130-133, LSU Graphic Service, Louisiana State University, Baton Rouge (Louisiana).

STUCKI T.P., 2000. Verbreitung der Flusskrebse in der Schweiz. In : Kurzfassung der Tagungsbeiträge, Internationale Fachtagung in Klagenfurt « Flusskrebse : Aktuelle Verbreitung, Gefährdung \& Schutz », Institut für Ökologie und Umweltplanung, Klagenfurt, 2-9 (unpublished).

UNESTAM T., 1975. The danger of introducing new crayfish species. In : AVAULT J.W. Jr. (ed.), Freshwater Crayfish, vol. 2, 557-561, Division of Continuing Education, Luisiana State University, Baton Rouge (Louisiana).

VORBURGER C., RIBI G., 1999a. Pacifastacus leniusculus and Austropotamobius torrentium prefer different substrates. In: KELLER M., KELLER M.M., OIDTMANNB., HOFFMANN R. and VOGT G. (Eds.), Freshwater Crayfish, vol. 12, 696-704, Weltbild Verlag, Augsburg.

VORBURGER C., RIBI G., 1999b. Aggression and competition for shelter between a native and an introduced crayfish in Europe. Freshwater Biology, 42, 111-119. 